\title{
THE INTEGRATED CURRICULUM OF UBC'S MASTER OF ENGINEERING LEADERSHIP PROGRAM IN CLEAN ENERGY ENGINEERING
}

\author{
Vladan Prodanovic and Walter Mérida \\ University of British Columbia \\ vladan.prodanovic@ubc.ca
}

\begin{abstract}
A new professional degree, Master of Engineering Leadership (MEL) has been introduced at the University of British Columbia. This collaborative effort between the Faculty of Applied Science and Sauder School of Business provides an innovative, integrated curriculum tailored to accelerate experienced engineers and early career professionals toward effective, sectorrelevant leadership roles. This integrated curriculum includes a rigorous engineering content as well as project management, communication and business development modules.

One area of specialisation, the MEL in Clean Energy Engineering (CEEN), provides advanced training across the energy industry value-chain: from sustainable energy generation and conversion technologies, to distribution, storage and management, smart distribution networks and energy policy. The program places students in an active learner's position and challenges them to critical thinking about topics related to energy conservation and efficiency, energy and environment, and social impact.

This paper will provide an overview of the curriculum and discuss different options for integration of course contents. It will discuss the impact of the program on the community, report on student reflections and feedback from industrial partners in the energy sector.
\end{abstract}

Keywords: UBC; MEL; Graduate Program; Clean Energy;

\section{INTRODUCTION}

Renewable sources of energy and sustainable energy technologies have carved their path in the energy sector, with electricity generated from renewables contributing to more than $45 \%$ of net additions to world capacity in the last two years [1]. Strong growth in demand, diversification of energy sources particularly in developing countries, declining renewable generation cost, more stringent implementation of regulations and enhanced policies, and growing concerns about local pollution continue to be major factors in positioning renewable sources to be the largest addition to power capacity. The International Energy Agency projects further expansion of the renewable energy to reach over $25 \%$ of the total energy production by 2020 with a significant focus on non-hydro sources. The anticipated global clean energy economy will top one trillion dollars.

Fossil-fuel based technologies, although still playing a dominant role in the energy sector, are forced to address issues of declining resources, climate change and pollution, and address governmental regulations, policy and the growing public concern. This leads to development of new cleaner technologies including, for example, hybrid technologies, energy storage and carbon capture.

This growth of the clean energy sector puts significant pressure on post-secondary institutions to educate professionals capable of addressing contemporary energy issues. Future leaders in this sector clearly need to have not only excellent technical knowledge, but also a good understanding of the roles of different stakeholders, knowledge of energy policy, business, management and leadership skills. On the undergraduate level, sustainability and energy topics are often embedded in the more traditional engineering disciplines, and in some cases special programs emerged with heavier focus on sustainability. Notable examples on the Canadian engineering education landscape are Carleton University with the B.Eng. in Sustainable and Renewable Energy Engineering, or the University of Toronto with the Energy Systems major or sustainable energy minor programs. In addition, a number of high quality specialised certified programs are offered in the college technology programs, for example the Alternative Energy program at NAIT Polytechnic, or the Sustainable Energy Management Advanced certificate (SEMAC) at BCIT.

Even a superficial look at the global engineering education database reveals over 100 Master programs in sustainable energy offered globally. Traditionally, strong post-graduate programs are offered in universities across north Europe (UK, Denmark, Sweden, Norway or Netherlands), many of them with international focus. There is also a growing demand for professional, non- 
research based programs in the United States and many are using online or mixed options to deliver courses. Some examples include the online Master of Professional Studies in Renewable Energy and Sustainability systems at Penn State University, Master of Science in Renewable and Clean Energy from University of Dayton, or Master of Science in Global Energy Management from University of Houston, all of which place an onus not only on technical expertise, but also on the energy economics, impact on society and the project development process.

Following the same rationale, a number of Canadian universities offer specialised programs on sustainable energy. The Institute for Sustainable Energy at the University of Toronto, for example, offers Graduate Emphasis in Sustainable Energy which is available to M.Eng., M.A.Sc., and Ph.D. students. The M. Sc. In Sustainable Energy Development (SEDV) is an interdisciplinary program offered through the Haskayne school of Business, Schulich School of Engineering and the Faculty of Graduate Studies, Law and Environmental Design. The interdisciplinary model is also present in other institutions, such as the M.Eng. in Environmental Engineering and M.A. in Sustainable Energy at Carleton University. A number of other schools also offer M.Eng. programs in environmental engineering (i.e. University of Regina, McGill University or Dalhousie University) or distance education (Renewable Energy Certificate, University of Toronto).

The University of British Columbia initiated an M.Eng. Program in Clean Energy Engineering in 2009, as the educational pillar of the Clean Energy Research Centre. In its six years of existence the program has achieved international recognition for its unique approach to a variety of clean energy related topics, and over 120 clean energy experts successfully graduated. In 2015 the Faculty of Applied Science adopted a different model for professional Master programs and launched the Master of Engineering Leadership (MEL) in Clean Energy Engineering. In this paper we present the motivation, program, learning outcomes and learning integration initiatives on the new MEL CEEN.

\section{MOTIVATION}

One very strong message that repeatedly comes across in discussions with different stakeholders in the energy sector is the need for engineering leaders in their chosen clean energy career path, with sector-relevant, cross disciplinary technical knowledge, combined with project management, communication an business skills. As pointed out by D. Reeve et al [2] the open literature on engineering leadership suggests that universities are finding different ways to address this problem through individual courses or integrated programs, or through extracurricular activities. Still, very few educational institutions offer this combination in technical master programs. This is why the University of BC has taken the initiative to develop o suite of professional programs (MEL) providing students with a comprehensive and innovative education different from the traditional nonresearch, course based Master of Engineering (M.Eng.) or the Master of Business Administration (MBA). The new MEL programs have been developed as a collaboration between the Faculty of Applied Science and the Sauder school of Business, and include 12 credits of business and management courses (platform courses) and 18 credits of technical sector-relevant courses.

The inclusion of the Clean Energy Engineering in the suite of new professional master programs (MEL CEEN) is a logical step forward. The Clean Energy Engineering M.Eng. program has been re-designed and re-structured such that it benefits greatly from the new platform courses, from strong leadership and academic excellence of host departments (Mechanical Engineering, and Chemical and Biological Engineering), while in the same time keeping its uniqueness and quality as the top clean energy engineering program in Canada with a strong link to the Clean Energy Research Centre.

\section{PROGRAM STRUCTURE}

The objective of MEL CEEN is to provide students with advanced knowledge in various aspects of energy conversion, distribution, storage and management, including renewable energy technologies, energy distribution networks and energy policy. It challenges students and position them to take an active role in critical thinking about energy conservation and efficiency, energy and environment, and social impact.

Students involved in the program must complete 30 credits of coursework. Twelve credits are dedicated to the Platform providing the professional skills required for an experienced graduate with an engineering background to be an effective manager, and 18 credits are dedicated to advanced technical courses. The courses are delivered following a calendar year, January - December, with the program start in January, and with a summer term dedicated to Co-op, industrial collaboration or entrepreneurship workshops. The program structure is shown in Table 1.

The Co-op program has been an important component of the program for many students in the previous CEEN program [3].It was highly valued by industrial partners of the program, and students appreciated the opportunity to gain practical experience and collaborate with industry. The Co-op component remains an option for the students in the new MEL CEEN. 
Table 1: Course Distribution.

\begin{tabular}{|c|c|}
\hline $\begin{array}{c}\text { Course name (number of } \\
\text { credits) }\end{array}$ & Duration \\
\hline $\begin{array}{l}\text { CEEN } 501 \text { Energy System } \\
\text { Fundamentals (3) }\end{array}$ & Jan-April \\
\hline $\begin{array}{l}\text { CEEN } 503 \text { Sustainable } \\
\text { Energy Systems (2) }\end{array}$ & Jan-April \\
\hline $\begin{array}{l}\text { CEEN } 523 \text { Energy \& the } \\
\text { Environment ( } 3 \text { ) }\end{array}$ & Jan-April \\
\hline $\begin{array}{l}\text { APPP } 501 \text { Project* } \\
\text { Management and Leadership } \\
(1.5)\end{array}$ & Jan-Feb \\
\hline $\begin{array}{l}\text { APPP } 503 \text { Organizational } \\
\text { Leadership (1.5) }\end{array}$ & Mar-April \\
\hline $\begin{array}{l}\text { APPP } 505 \text { Analytics \& } \\
\text { Interpretation for Applied } \\
\text { Science (3) }\end{array}$ & Jan-April \\
\hline $\begin{array}{l}\text { Optional Co-op or e@UBC } \\
\text { Lean Launchpad } \\
\text { (entrepreneurship workshop) }\end{array}$ & May-July \\
\hline $\begin{array}{l}\text { APPP } 504 \text { Business Acumen } \\
\text { for Technical Leaders ( } 3 \text { ) }\end{array}$ & August \\
\hline $\begin{array}{l}\text { CEEN } 504 \text { Energy Storage } \\
\text { and Transmission ( } 2 \text { ) }\end{array}$ & Sep-Dec \\
\hline $\begin{array}{l}\text { CEEN } 550 \text { Energy Efficiency } \\
\text { and Conservation (3) }\end{array}$ & Sep-Dec \\
\hline CEEN 525 Energy Policy (2) & Sep-Dec \\
\hline $\begin{array}{l}\text { APPP } 506 \text { Capstone Project } \\
\text { (3) }\end{array}$ & Sep-Dec \\
\hline $\begin{array}{l}\text { APPP } 502 \text { Leadership \& } \\
\text { Sustainability (1.5) }\end{array}$ & Sep-Oct \\
\hline $\begin{array}{l}\text { SAUDER BUSINESS } \\
\text { ELECTIVE }(1.5)\end{array}$ & Nov-Dec \\
\hline
\end{tabular}

Platform courses are shown in grey boxes*

The technical courses have been clustered along the industry value chain: Energy Generation, Transmission and Distribution, Energy Utilisation and Management they are delivered in the order illustrated in Table 1.

Platform courses are delivered in collaboration with the Sauder School of Business, and they provide an opportunity for exchange of ideas with other MEL students in different masters programs, and with different technical background.
The capstone project is a real-world multidisciplinary project carried out in collaboration with an industrial mentor (mandatory for the project), and relevant to student's chosen career path. Capstone project proposals are brought into the program by students, who often also suggest industrial mentors. These projects cover a very broad range of topics, from feasibility studies about renewable options for remote, off grid sites, development of community energy plans for First Nations communities, to very specific benchmarking and energy conservation project for green buildings or industrial energy efficiency projects.

\section{CURRICULUM INTEGRATION}

The learning outcomes of the program are as follows:

- Comprehensive technical and practical understanding of conventional thermal systems and alternative energy technologies;

- Understanding of energy storage and transportation in terms of both technology and optimization;

- Comprehensive technical and operational understanding of Strategic Energy Management;

- Comprehensive understanding of the impact of various energy systems on the ecosystems and environment, and potential routes to reducing pollution and developing sustainable clean energy systems;

- Understanding of the social and political dimension of energy efficiency and conservation, energy policy and economics;

These learning outcomes provide opportunities for curriculum integration with focus on interdisciplinary, real-world applications and involvement of multiple stakeholders. There is substantial evidence that interdisciplinary case studies and real-world projects significantly enhance student learning experience $[4,5]$.

Examples of curriculum integration which are applied in this program include:

- Integration of platform and technical courses through project work (i.e. managing "big data" in APPP 505 from real-world data sets in energy sector);

- Integration of technical courses along the industry value chain through case studies;

- Integration of Co-op and capstone project work on projects of interest to both the student and industrial partner.

As an example of integration across technical courses we provide a short description of a case study on the ANDASOL-1 Concentrated Solar Power Plant for production of $50 \mathrm{MW}$ of electrical power. This case study has been presented to the students in their first term, 
during with they covered topics in thermodynamics (CEEN 501), solar power (CEEN 503) and life cycle analysis (CEEN 523). The students were provided with simulation tools for energy modeling of the solar field and the power block, and they were presented with a comprehensive study of the life cycle cost analysis, policy and governmental incentives for renewable energy production at the location of the plant (Spain). Simulation tools and calculation predictions were discussed in respective technical courses.

Equipped with such tools, the students can further be asked to present a feasibility study of a similar plant in a different location, taking into account technical aspects of implementing such project, as well as its impact on the environment and society. Evaluation of students' understanding of the topics can be incorporated in the marking scheme of different courses.

It should be mentioned that this case study was only a pilot project in the new MEL CEEN, but after receiving a very positive students' feedback further work on developing similar case studies, and evaluation parameters across different courses is underway.

\section{CONCLUSION}

A new concept of professional Master programs (MEL) launched at UBC has been presented. The new programs focus on development of interdisciplinarity and leadership capability, and incorporate technical as well as professional skills (business, management and leadership).

Among MEL programs, a real success story is the Master in Clean Energy Engineering (MEL CEEN). This program builds on the successful foundation of the previous M.Eng. in Clean Energy Engineering, provides an integrated curriculum appropriate for the goals and vision of MEL, and continues to educate students in the area of renewable energy technologies, energy efficiency and energy policy.

\section{References}

[1] "Medium-Term Renewable Energy Market Report 2015 Market Analysis and Forecast to 2020", International Energy Agency (IEA) Publications, from http://www.iea.org

[2] Doug Reeve, Robin Sacks and Cindy Rotmann, "A Responsibility to Promote Leadership: Engineering Entrepreneurs Speak Back to Resistance", in Proc. CEEA Canadian Engineering Education Assoc. Conf., CEEA 2014, (Canmore, AB; June 2014)

[3] Jenny Reilly and Tatiana Teslenko, "Enhancing ESD Through the Master of Clean Energy Engineering Co-op Program: A Canadian Case-Study", Integrative Approaches to Sustainable Development at University Level, W. Leal Filho et al. (eds), World Sustainability Series, Springer, 2015

[4] Richard Chiou and Radian Belu, "Student Learning Experience from Renewable Energy Case Studies", in Proc. $120^{\text {th }}$ ASEE Annual Conference \& Exposition, (Atlanta, Georgia, June 2013)

[5] Oxana Pantchenko and Tiffany Wise-West, "Enhancing Student Learning Through a Real-World Project in a Renewable Energy Courses Course", in Proc. $120^{\text {th }}$ ASEE Annual Conference \& Exposition, (Atlanta, Georgia, June 2013) 